\title{
Tohumları farklı NaCl dozları ile muamele edilen mısırın tuzlu topraklarda fide gelişiminin belirlenmesi
}

Determination of seedling growth of maize in responce to seed priming with different $\mathrm{NaCl}$ doses in saline soils

\author{
Aybüke KAYA ${ }^{1}$, Hüseyin GÖZÜBENLi²
}

${ }^{1}$ Hatay Mustafa Kemal University, Faculty of Agriculture, Department of Agricultural Economics, Antakya-Hatay, Turkey.

${ }^{2}$ Hatay Mustafa Kemal University, Faculty of Agriculture, Department of Field Crops, Antakya-Hatay, Turkey.

MAKALE BILGISI / ARTICLE INFO

Makale tarihçesi / Article history:

DOI: $\underline{10.37908 / m k u t b d .755170}$

Geliş tarihi /Received:30.06.2020

Kabul tarihi/Accepted:11.08.2020

\section{Keywords:}

Maize, salinity, tolerance, $\mathrm{NaCl}$.

Corresponding author: Hüseyin
GÖZÜBENLi
$\square: \underline{\text { hgbenli@mku.edu.tr }}$

\section{ÖZET / A BSTRACT}

Atıf / Citation: Kaya A, Gözübenli H (2020) Tohumları farklı nacl dozları ile muamele edilen mısırın tuzlu topraklarda fide gelişiminin belirlenmesi. MKU. Tar. Bil. Derg. 25(3) : 394-405. DOI: 10.37908/mkutbd.755170

\section{Giriş}

Dünyada değişik iklim kuşaklarına adapte olabilen mısır bitkisi (Zea mays L.) Gramineae familyasının Maydeae oymağına ait olup, tahıllar içerisinde birim alan basına düşen geliri yüksek olan bitkilerden birisidir (Shaw, 1988).

TÜik 2019 yılı verilerine göre; ekim alanı 6380650 da, mısır üretimi 6 milyon ton olup, verimi ise $940 \mathrm{~kg} / \mathrm{da}^{\prime}$ dır.
Türkiye' de mısır bitkisinin son 20 yıldaki geçmişine baktı̆̆ımızda ekim alanı, üretim ve verimde önemli artışlar görülmüştür. Ayrıca Güneydoğu Anadolu Projesi ile sulama olanaklarının artması, yeni teknoloji kullanım düzeyinin artması, hibrit tohum kullanıcı sayısındaki artış ve üretim tekniklerinin iyileşmesi ile birlikte Türkiye mısır verim ortalaması, dünya verim ortalamasından daha yüksek duruma gelmiştir. 
Dünyada ve ülkemizde tuzlu toprakların miktarı her geçen gün artmakta, verim azalmakta ve bazı alanlar aşırı tuzlanma nedeniyle tamamen tarımsal üretim faaliyetlerinin yapılamadığı bir alan halini almaktadır. Yeryüzünde işlenebilir olan toplam tarım alanının \% 13 'ünde tuzluluk problemi ortaya çıkmıştır. Türkiye'de yaklaşık 1,5 milyon hektar toprakta tuzluluk ve alkalilik problemi olduğu belirlenmiştir (Sönmez, 2004). Amik ovasında yer alan toprak serileri incelendiğinde temel kimyasal ve fiziksel özelliklerini belirlemek için yapılan bir çalışmada, çalışma alanında bulunan 29 farklı toprak serisinde topraklarının $\mathrm{pH}$ değerlerinin 7.21 - 8.42 arasında olduğu belirlenmiş olup, toplam tuz içeriğinin \% $0.020-0.780$ arasında olduğunu ve toprakların yarıya yakınında tuzluluk problemi olduğunu belirlemiştir (Yalçın, 2004). Ovanın değişik yerlerinde yapılan diğer bir çalışmada; Reyhanlı ilıçesi'nde eski göl tabanında jips mineralinin kapilariteyle yüzeye kadar çıktığı ve toprağın tuzlanması üzerinde etkili olduğu belirtilmiştir (Atasoy ve Geçen, 2013 ).

Toprak çözeltisinde kalsiyum klorür, magnezyum klorür, sodyum klorür, magnezyum sülfat, sodyum bikarbonat, sodyum sülfat ve kalsiyum sülfat gibi birçok tuz formu bulunmaktadır. Ancak bitkisel üretim bakımından en fazla hasar ve verim kaybına neden olan tuz formunun $\mathrm{NaCl}$ olduğu Marschner, (1995) tarafından bildirilmiştir. Tuzluluğun yeryüzündeki en önemli toprak sorunlarından biri olduğu ve toprakta biriken tuzların, toprağın fiziksel ve kimyasal yapısını bozarak bitki gelişimini etkileyerek verim azalışına yol açtığı belirtilmiştir (Ekmekçi ve ark., 2005). Ayrıca tuzluluğun bitkide yaş ve kuru ağırlığı, kök uzunluğunu ve $\mathrm{K}^{+} / \mathrm{Na}^{+}$ oranını, $\mathrm{Ca}^{+2} / \mathrm{Na}^{+}$oranını azalttığı (Akram ve ark., 2010), belirli dozdaki tuzlu suyla muamele (priming) edildikten sonra tuzlu toraklarda yetiştirilen mısır çeşitlerinin, çimlenme çıkış süresi, bitki boyu, yaş ve kuru ağırlık, $\mathrm{Na}$ ve $K$ içeriği gibi özelliklerinde önemli olumlu etkiler olduğu (Bakht ve ark., 2011), tuzluluğun ozmotik basıncı arttırdığı, bitkilerin topraktan su alımını ve besin maddelerinin alımını sınırlandırdığı (Ekmekçi ve ark., 2005), tuzluluğun etkisini genellikle mısır tohumlarının çimlenme ve erken fide dönemindeyken kendini gösterdiği, köklerin sürgünlere göre daha fazla etkilendiği ve tohuma $\mathrm{NaCl}$ ile ön uygulamanın mısır tohumlarının özellikle çimlenmesini ve gelişmesini teşvik ettiği (Abraha ve Yohannes, 2013) bildirilmiştir. Farklı tuz konsantrasyonlarının bazı yerel patlak mısır ve hibrid mısır genotiplerinin çimlenme özellikleri üzerine olumlu etki yaptığı ve artan tuz konsantrasyonlarının olumsuz etki yaptığı (idikut ve ark., 2012), mısır tohumlarında GA (Gibberellic acid), $\mathrm{NaCl}$ ve PEG( polyethylene glycol) ön uygulamalarının çimlenme fide gelişimi ve tohum verimi üzerine etkilerinin incelemek için yapılan çalışma sonucunda çimlenme özellikleri yönünden tohuma yapılan ön muamelenin etkin bir yöntem olduğu (Tian ve ark. 2014) belirtilmiştir.

Bu çalışma, $\mathrm{NaCl}^{\prime}$ nin farklı dozları ile farklı sürelerde ( 0 $\mathrm{g} \mathrm{l}^{-1}, 5 \mathrm{~g} \mathrm{l}^{-1}$ ve $10 \mathrm{~g} \mathrm{l}^{-1} \mathrm{NaCl}$ dozlarında 12 ve 24 saat sürelerle ) muamele edilen mısır tohumlarının farklı düzeylerde tuz içeren (kontrol, $6 \mathrm{dS} \mathrm{m}^{-1}$ ve $12 \mathrm{dS} \mathrm{m}^{-1}$ ) topraklarda, mısırın fide gelişimi incelemek amacıyla yapılmıştır.

\section{MATERYAL ve YÖNTEM}

Araştırma, 2014 yılı mısır yetiştirme sezonunda, iki farklı mısır çeşidi (Pasha ve P-31A34) kullanılarak yürütülmüştür.

Çalışma tesadüf parsellerinde faktöriyel deneme desenine göre 4 tekrarlamalı olarak yürütülmüştür. Çalışmada; çeşitler (Pasha ve P-31A34) ana parsellerde, toprak tuzluluk düzeyleri (kontrol, $6 \mathrm{dS} \mathrm{m}^{-1}$ ) ve $12 \mathrm{dS} \mathrm{m}$ $\left.{ }^{1}\right)$ alt parsellerde, tohuma uygulanan $\mathrm{NaCl}$ dozları $\left(0 \mathrm{~g}^{-1}\right.$, $\left.5 \mathrm{~g} \mathrm{l}^{-1}, 10 \mathrm{~g} \mathrm{l}^{-1}\right)$ alt-alt parsellerde ve uygulama süreleri (12 saat ve 24 saat) alt-alt-alt parsellerde yer almıştır.

Bu araştırmada kullanılan topraklar; $6 \mathrm{dS} \mathrm{m}^{-1}$ ve $12 \mathrm{dS} \mathrm{m}$ ${ }^{1}$ tuzluluk düzeyleri oluşturmak için gerekli tuz $(\mathrm{NaCl})$ miktarını içeren ve tarla kapasitesine ulaştıracak miktarda su ile sulanarak kuruması beklenmiştir ve kuruduktan sonra karıştırılıp denemede kullanılmıştır.

Denemede kullanılan tohumlar \% 1 lik sodyum hypochlorid solüsyonunda 5 dakika yüzey sterilizasyonu yapıldıktan sonra 3 defa 2'şer dakika saf su ile yıkandıktan sonra $0 \mathrm{~g} \mathrm{l}^{-1}, 5 \mathrm{~g} \mathrm{l}^{-1} \mathrm{ve} 10 \mathrm{~g} \mathrm{l}^{-1} \mathrm{NaCl}$ olarak hazırlanan solüsyonlarda 12 ve 24 saat sürelerle $25^{\circ} \mathrm{C}^{\prime}$ de bekletilmiş olup, süre sonunda, \% 15 nem seviyesine gelene kadar oda koşullarında kurutulmuştur.

Deneme $18 \mathrm{~cm}$ çapında ve $15 \mathrm{~cm}$ yüksekliğinde saksılara tuzun yıkanmasını engellemek amacıyla $3 \mathrm{~kg}^{\prime} \mathbf{l}^{\prime} \mathrm{k}$ polietilen torba yerleştirilerek, her saksıya $2 \mathrm{~kg}$ kuru toprak konulmuş ve her saksıya yaklaşık $3 \mathrm{~cm}$ derinliğinde 5 adet mısır tohumu ekimi yapılmıştır. Her saksıya ekimle birlikte, 10 gün sonra ve 20 gün sonra 100 $\mathrm{mg} \mathrm{kg}^{-1} \% 33^{\prime}$ lük amonyum nitrat gübresi uygulanmıştır. Tohum ekimi yapıldıktan sonra toprağı tarla kapasitesine ulaştırmak için gereken su miktarı verilmiştir. Daha sonraki sulamalar için saksılar düzenli olarak tartılarak topraktaki kullanılabilir suyun yaklaşık yarısı tüketildiğinde sulama yapılmıştır. Bitkiler çıkış yaptıktan sonra her saksıda 3 bitki olacak şekilde seyreltme yapılmıştır.

Çalışma ekimden 1 ay sonra sonlandırılmış olup; bitki boyu, kök yaş ağırlığı, sap yaş ağırlığı, kök kuru ağırlığı, 
sap kuru ağırlığı, tuz tolerans indeksi kök ve sap azot (N) içerikleri belirlenmiştir.

Araştırmada elde edilen veriler Mstat-C istatistik programı kullanılarak, tesadüf parsellerinde faktöriyel deneme desenine göre varyans analizi yapılarak ortalamaların karşılaştırılması LSD (EGF) testine göre yapılmıştır.

\section{BULGULAR ve TARTIŞMA}

\section{Bitki Boyu}

Bitki boyu değerleri yönünden toprak tuzluluğu, $\mathrm{NaCl}$ dozu, muamele süresi, çeşit $x$ toprak tuzluluğu etkileşiminin önemli olduğu belirlenmiştir.

Çizelge 1 incelendiğinde bitki boyu yönünden çeşitler arasındaki farkın istatistiksel olarak önemli olmadığı, P 31A34 çeşidinin bitki boyu $(38.24 \mathrm{~cm})$ ile, Pasha çeşidinin bitki boyunun $(37.90 \mathrm{~cm})$ birbirine yakın olduğu görülmektedir.

Farklı toprak tuzluluğu uygulamalarında belirlenen bitki boyu değerleri $34.70 \mathrm{~cm}-40.37 \mathrm{~cm}$ arasında değişmiş olup en uzun bitki boyu $40.37 \mathrm{~cm}$ ile kontrol grubu toprak tuzluluğunda, en kısa bitki boyu ise $34.70 \mathrm{~cm}$ ile EC 12 toprak tuzluluğunda belirlenmiştir (Çizelge 1). Topraktaki artan tuz yoğunluğundan bitki boyu olumsuz yönde etkilenmiştir. Artan tuz konsantrasyonunun mısırda morfolojik gelişme üzerine olumsuz etkileri de arttırdığı (Koçer, 2007), mısır bitkisinde stres koşullarının artmasıyla birlikte bitki boyu, gövde çapı, gövde ve kök yaş-kuru ağırlığı gibi özellikleri azalttığı Köşkeroğlu (2006) tarafından da bildirilmiştir.

Tohumlara uygulanan farklı $\mathrm{NaCl}$ dozlarında (priming) belirlenen bitki boyu değerleri $37.33 \mathrm{~cm}-38.52 \mathrm{~cm}$ arasında değişmiş olup, en uzun bitki boyu değerleri $5 \mathrm{~g}$ $\mathrm{I}^{-1}$ uygulamasında görülürken kontrol grubunda bitki boyunun daha kısa olduğu görülmüştür (Çizelge 1). Tian ve ark., (2014); Sathish ve ark.(2011); Miraj ve ark. (2013); Aymen ve Cherif, (2013); Bajehbaj (2010); Khan ve ark. (2009) çalışmalarında hem mısır hem de farklı tohumlarda yapılan ön uygulamaların çimlenme performansı, fide gelişimi ve verim yönünden tohuma yapılan ön muamelenin etkin bir yöntem olduğunu önermişlerdir.

$\mathrm{NaCl}$ dozlarının muamele süreleri incelendiğinde ortalama bitki boyu değerleri $37.46 \mathrm{~cm}-38.74 \mathrm{~cm}$ arasında değiştiği görülmüş olup; en uzun bitki boyu $(38.74 \mathrm{~cm}) 24$ saatlik uygulamada görülürken, kontrol grubu uygulamasında $37.47 \mathrm{~cm}$ olarak tespit edilmiştir (Çizelge 1).

Çizelge 1. Farklı çeşit, toprak tuzluluğu, $\mathrm{NaCl}$ dozu ve muamele süresi uygulamalarında belirlenen fide özelliklerine ilişkin ortalama değerler ve EGF çoklu karşılaştırma testine göre oluşan gruplar

Table 1.Average values for seedling properties determined in different cultivars, soil salinity, $\mathrm{NaCl}$ dosage and treatment time applications and groups occurred according to EGF multiple comparison test

\begin{tabular}{|c|c|c|c|c|c|}
\hline & Bitki Boyu & Sap Yaş Ağırlığı & Kök Yaş Ağırlığı & Sap Kuru Ağırlığı & Kök Kuru Ağırlığı \\
\hline \multicolumn{6}{|l|}{ Çeşitler } \\
\hline PASHA & 37.90 & $3.03 a$ & $2.26 \mathrm{a}$ & $0.41 a$ & $0.22 a$ \\
\hline $\mathrm{P}-31 \mathrm{~A} 34$ & 38.24 & $2.20 \mathrm{~b}$ & $2.10 \mathrm{~b}$ & $0.34 \quad b$ & $0.19 \mathrm{~b}$ \\
\hline \multicolumn{6}{|c|}{ Toprak Tuzluluğu } \\
\hline Kontrol & $40.37 a$ & 3.16 a & $2.76 \mathrm{a}$ & $0.43 a$ & $0.27 \mathrm{a}$ \\
\hline $6 \mathrm{dS} \mathrm{m^{-1 }}$ & $39.14 b$ & $2.55 \mathrm{~b}$ & $2.44 \mathrm{~b}$ & $0.38 \quad \mathrm{~b}$ & $0.22 \mathrm{~b}$ \\
\hline $12 \mathrm{dS} \mathrm{m}^{-1}$ & $34.70 \mathrm{c}$ & $2.14 \mathrm{c}$ & $1.34 \mathrm{c}$ & $0.32 \mathrm{c}$ & $0.12 \mathrm{c}$ \\
\hline \multicolumn{6}{|l|}{$\mathrm{NaCl}$ Dozu } \\
\hline $0 \mathrm{~g} \mathrm{l}^{-1}$ & $37.33 \mathrm{~b}$ & 2.55 & 2.13 & 0.37 & 0.20 \\
\hline $5 \mathrm{~g} \mathrm{l}^{-1}$ & 38.52 a & 2.64 & 2.17 & 0.38 & 0.20 \\
\hline $10 \mathrm{~g} \mathrm{l}^{-1}$ & 38.36 a & 2.67 & 2.24 & 0.38 & 0.21 \\
\hline \multicolumn{6}{|c|}{ Muamele Süresi } \\
\hline Kontrol & $37.46 \mathrm{~b}$ & $2.71 \mathrm{a}$ & $2.41 \mathrm{a}$ & $0.39 a$ & $0.22 a$ \\
\hline 12 Saat & $38.02 \mathrm{~b}$ & $2.55 \mathrm{~b}$ & $1.97 \mathrm{c}$ & $0.37 \mathrm{~b}$ & $0.19 \mathrm{~b}$ \\
\hline 24 Saat & $38.74 \quad a$ & $2.60 \mathrm{ab}$ & $2.16 \mathrm{~b}$ & $0.37 \quad b$ & $0.20 \mathrm{~b}$ \\
\hline EGF (\%5) & 0.7186 & 0.1154 & 0.1442 & 0.01472 & 0.01041 \\
\hline
\end{tabular}

Aynı harf grubuna giren ortalamalar arasındaki fark EGF testine göre \% 5 düzeyinde önemli değildir. 
Bitki boyu yönünden çeşitlerin toprak tuzluluğuna tepkisinin farklı olduğu belirlenmiş olup, farklı çeşit $x$ toprak tuzluluğu etkileşiminde; en uzun bitki boyu (41.40 cm) P - 31A34 çeşidinde kontrol grubunda, en kısa bitki boyu $(33.89 \mathrm{~cm})$ yine $P$ - 31A34 çeşidinde EC 12 toprak tuzluluğunda tespit edilmiştir (Şekil 1).
P - 31A34 çeşidinin toprak tuzluluğuna tepkisi Pasha çeşidine göre daha fazla olduğundan çeşit $x$ toprak tuzluluğu interaksiyonu önemli çıkmıştır (Şekil 1). Çeşitlerin tuzluluğa tepkisinin farklılık gösterdiği İdikut ve ark. (2012) tarafından da bildirilmiştir.

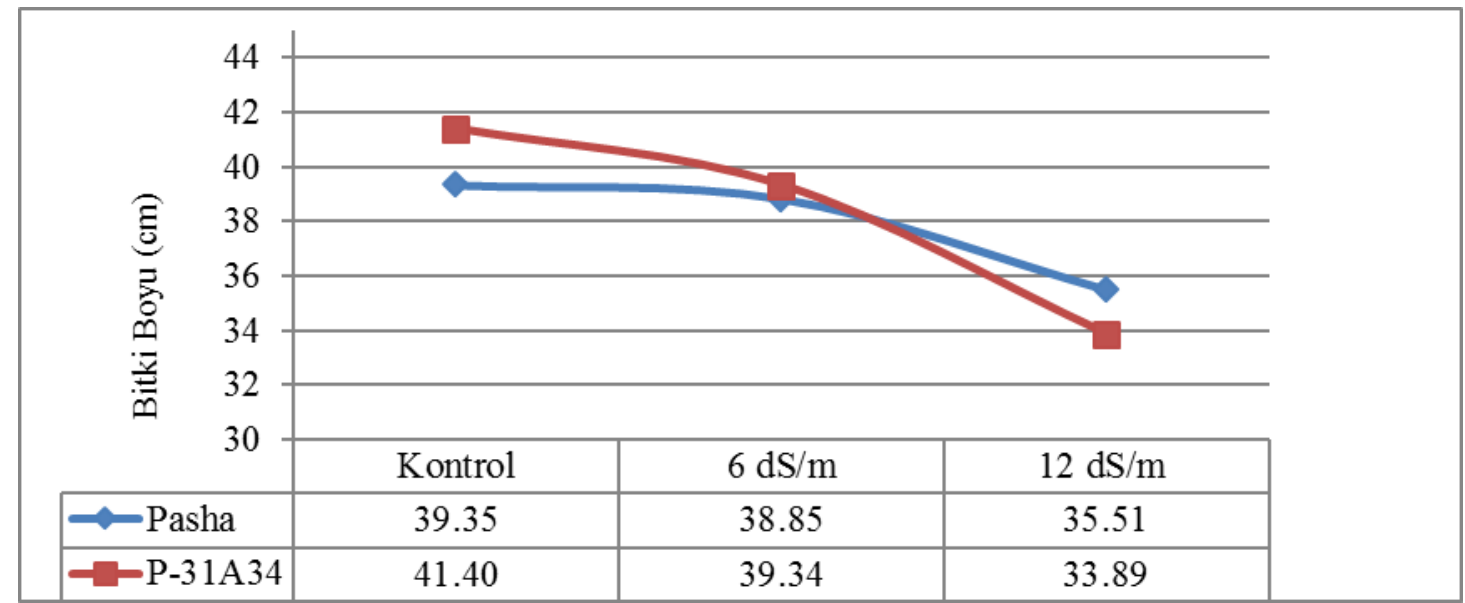

Şekil 1. Çeşit $x$ toprak tuzluluğu etkileşiminde belirlenen bitki boyuna ilişkin ortalama değerler Figure 1. Average values for plant height determined in the interaction of variety $x$ soil salinity

\section{Sap Yaş Ağırlığı}

Sap yaş ağırlığı değerleri yönünden çeşit, toprak tuzluluğu ve muamele süresinin önemli olduğu belirlenmiştir (Çizelge 1).

Sap yaş ağırlığı Pasha çeşidinde daha yüksek (3.03 g bitki ${ }^{1}$ ) bulunurken, $\mathrm{P}$ - $31 \mathrm{~A} 34$ çeşidinde daha düşük (2.20 g bitki $^{-1}$ ) bulunmuştur (Çizelge 3 ).

Farklı toprak tuzluluklarında belirlenen sap yaş ağırlığı değerleri 2.14 - $3.16 \mathrm{~g} \mathrm{bitki}^{-1}$ arasında değişmiş olup; en yüksek sap yaş ağırlığı $3.16 \mathrm{~g}$ bitki $^{-1}$ ile kontrol grubunda belirlenirken, en düşük sap yaş ağırlığı değeri ise $2.14 \mathrm{~g}$ bitki $^{-1}$ ile $12 \mathrm{dS} \mathrm{m}^{-1}$ toprak tuzluluğunda belirlenmiştir (Çizelge 1). Tuzluluk stresinden dolayı bitkinin yeşil aksam büyümesinde ortaya çıkan azalmaların, kök büyümesinde ortaya çıkan azalmalardan daha fazla olduğu bildirilmektedir (Eker ve ark., 2006).

Tohumlara uygulanan farklı $\mathrm{NaCl}$ dozlarında (priming) belirlenen sap yaş ağırlığı değerleri 2.55 - 2.67 g bitki $^{-1}$ arasında değişmiş, ancak fark istatistiki olarak önemsiz bulunmuştur (Çizelge 3 ).

$\mathrm{NaCl}$ dozlarının muamele süreleri incelendiğinde ortalama sap yaş ağırlığı 2.55 - $2.71 \mathrm{~g} \mathrm{bitki}^{-1}$ arasında değiştiği görülmüş olup; en iyi sap yaş ağırlığı 2.71 g bitki 1 ile kontrol grubunda tespit edilmiştir (Çizelge 3 ).

\section{Sap Kuru Ağırlığı}

Sap kuru ağırlığı değerleri yönünden çeşit, toprak tuzluluğu, muamele süresi ve çeşit $x$ muamele süresi etkileşiminin önemli olduğu belirlenmiştir (Çizelge 4).
Sap kuru ağırlığı yönünden Pasha çeşidinin (0.41 g bitki $\left.{ }^{1}\right) \mathrm{P}$ - $31 \mathrm{~A} 34$ çeşidine $\left(0.34 \mathrm{~g} \mathrm{bitki}^{-1}\right)$ göre daha iyi olduğu saptanmıştır (Çizelge 1).

Farklı toprak tuzluluğunda belirlenen sap kuru ağırlıkları 0.32 - $0.43 \mathrm{~g} \mathrm{bitki}^{-1}$ arasında değişmiş olup; en yüksek sap kuru ağırlığı değeri $0.43 \mathrm{~g} \mathrm{bitki}^{-1}$ ile kontrol grubunda, en düşük sap kuru ağırlığı değeri ise $0.32 \mathrm{~g} \mathrm{bitki}^{-1}$ ile $12 \mathrm{dS}$ $\mathrm{m}^{-1}$ toprak tuzluluğunda belirlenmiştir (Çizelge 4). Toprak tuzluluğundaki artışla sap kuru ağırlık miktarlarında da kademeli olarak bir azalma olduğu bazı araştırıcılar tarafından da tespit edilmiştir (Ayman ve ark., 2014; Bakth ve ark., 2011; Akram ve ark., 2010; Aktaş ve ark., 2006; Atış, 2011). Çelik (2014), NaCl' nin artan dozları bitkinin yaş ve kuru ağırlığını kontrole göre önemli oranda azalttığını belirtmiştir. $\mathrm{NaCl}$ uygulamasının bitkilerde yeşil aksam kuru madde miktarını azalttığı belirlenmiştir.

Tohumlara uygulanan farklı $\mathrm{NaCl}$ dozlarında (priming) belirlenen sap kuru ağırlıkları arasındaki fark istatistiki olarak önemsiz bulunmuştur (Çizelge 4). Tohuma uygulanan farklı $\mathrm{NaCl}$ dozlarının sap kuru ağırlığına fazla etkisinin olmadığı saptanmıştır.

$\mathrm{NaCl}$ dozlarının (priming) muamele süreleri incelendiğinde ortalama sap kuru ağırlığı 0.37 - 0.39 g bitki $^{-1}$ arasında değiştiği görülmüş olup; en yüksek sap kuru ağırlığı (0.39 $\left.\mathrm{g} \mathrm{bitki}^{-1}\right)$ kontrol grubunda tespit edilmiştir (Çizelge 1). 


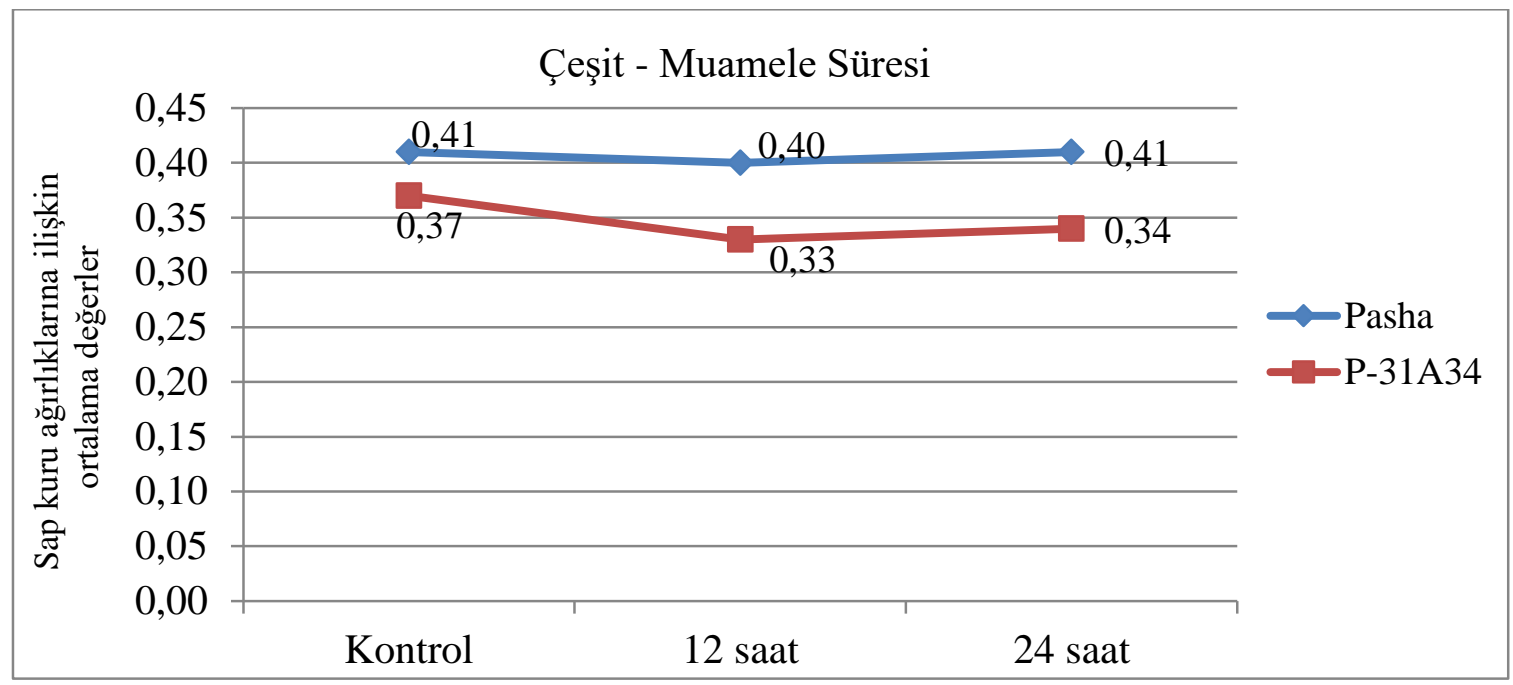

Şekil 2. Çeşit x muamele süresi etkileşiminde belirlenen sap kuru ağılıklarına ilişkin ortalama değerler Figure 2. Average values for stem dry weights determined in the interaction of variety $x$ treatment time

Pasha çeşidi muamele sürelerine fazla tepki vermezken, P-31A34 çeşidinde muamele sürelerine göre kontrol grubunda değerlerin biraz yüksek olması çeşit $x$ muamele süresi etkileşiminin sap kuru ağırlıkları yönünden istatistiki olarak önemli çıkmasına neden olmuştur (Şekil 2).

\section{Kök Yaş Ağırlığı}

Kök yaş ağırlığı değerleri yönünden çeşit, toprak tuzluluğu, muamele süresi ve çeşit $x$ toprak tuzluluğu etkileşiminin önemli olduğu belirlenmiştir.

Kök yaş ağırlığı Pasha çeşidinde daha yüksek (2.26 g bitki$\left.{ }^{1}\right)$ olurken $\mathrm{P}$ - $31 \mathrm{~A} 34$ çeşidinde daha düşük (2.10 g bitki $\left.{ }^{-1}\right)$ olmuştur (Çizelge 1 ).

Farklı toprak tuzluluklarında belirlenen kök yaş ağırlıkları 1.34 - $2.76 \mathrm{~g} \mathrm{bitki}^{-1}$ arasında değişmiş olup en fazla ağırlık $2.76 \mathrm{~g} \mathrm{bitki}^{-1}$ ile kontrol grubunda, en az ağırlık ise $1.34 \mathrm{~g}$ bitki $^{-1}$ ile $12 \mathrm{dS} \mathrm{m}^{-1}$ toprak tuzluluğunda belirlenmiştir (Çizelge 1). Toprak tuzluluğundaki artışla kök yaş ağırlığı miktarlarında kademeli olarak bir azalma olduğu tespit edilmiştir. Akram ve ark., (2010) tarafından da tuzluluğun bitkide yaş ve kuru ağırlığı, kök uzunluğunu azalttı̆̆ı tespit edilmiştir. Stres koşullarının artmasıyla birlikte bitki boyu, gövde çapı, gövde ve kök yaş - kuru ağırlığı azalmaktadır (Köşkeroğlu, 2006).

Farklı çeşit $\mathrm{x}$ toprak tuzluluğu etkileşiminde kök yaş ağırlı̆ı yönünden çeşitlerin toprak tuzluluklarına tepkisi istatistiki olarak önemli bulunmuş olup; en fazla kök yaş ağırlığı $3.09 \mathrm{~g} /$ bitki ile Pasha çeşidinde kontrol grubunda, en az ağırık ise $1.3 \mathrm{~g} \mathrm{bitki}^{-1}$ ile P- $31 \mathrm{~A} 34$ çeşidinde $12 \mathrm{dS}$ $\mathrm{m}^{-1}$ toprak tuzluluğunda saptanmıştır (Şekil 3).

Pasha çeşidinde toprak tuzluluğunun artmasıyla orantılı olarak kök yaş ağırlığında düşüş görülürken P-31A34 çeşidinde $6 \mathrm{dS} \mathrm{m}^{-1}$ toprak tuzluluğunda düşüş görülmeyip hafif bir artış görülmüş, daha yüksek $\left(12 \mathrm{dS} \mathrm{m}^{-1}\right)$ toprak tuzluluğunda ise düşüş görülmüştür (Şekil 3). Çeşitlerin toprak tuzluluğuna tepkisinin farklı olması interaksiyonun önemli çıkmasına neden olmuştur. 


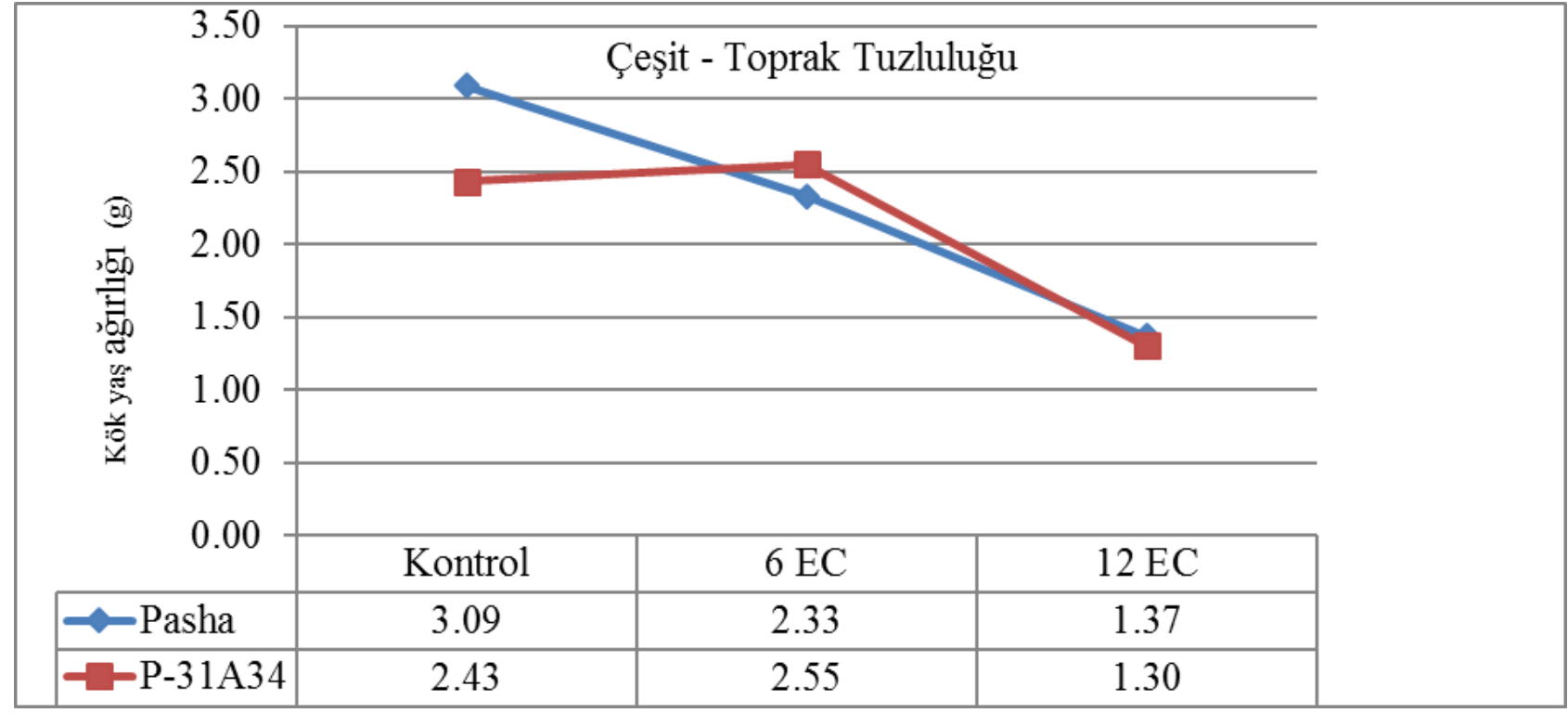

Şekil 3. Çeşit $x$ toprak tuzluluğu etkileşiminde belirlenen kök yaş ağırlıklarına ilişkin ortalama değerler

Figure 3. Average values for root fresh weights determined in the interaction of variety $x$ soil salinity

\section{Kök Kuru Ağırlı̆̆ı}

Kök kuru ağırlığı değerleri yönünden çeşit, toprak tuzluluğu, muamele süresi ve çeşit $x$ toprak tuzluluğu etkileşiminin önemli olduğu belirlenmiştir.

Çeşitlerin kök kuru ağırlıkları incelendiğinde, Pasha çeşidinde $0.22 \mathrm{~g}^{\text {bitki }}{ }^{-1}$ olarak belirlenirken, $\mathrm{P}$ - 31A34 çeşidinde $0.19 \mathrm{~g} \mathrm{bitki}^{-1}$ olarak belirlenmiştir (Çizelge 1 ). Farklı toprak tuzluluklarında belirlenen kök kuru ağırlıkları $0.12-0.27 \mathrm{~g} / \mathrm{bitki}$ arasında değişmiş olup en fazla ağırlık $0.27 \mathrm{~g} \mathrm{bitki}^{-1}$ ile kontrol grubu toprak tuzluluğunda, en düşük ağırlık ise $0.12 \mathrm{~g} \mathrm{bitki}^{-1}$ ile $12 \mathrm{dS}$ $\mathrm{m}^{-1}$ toprak tuzluluğunda belirlenmiştir (Çizelge 1). Toprak tuzluluğundaki artışla kök kuru ağırlık miktarlarında da kademeli olarak bir azalma olduğu Akdoğan ve Özkan (2000) tarafından da tespit edilmiştir. Çelik (2014) $\mathrm{NaCl}^{\prime}$ nin artan dozları bitkinin yaş ve kuru ağırlığını kontrole göre önemli oranda azalttığını belirtmiştir.

Tohumlara uygulanan farklı $\mathrm{NaCl}$ dozlarında (priming) belirlenen kök kuru ağırlığı değerleri incelendiğinde kullanılan $\mathrm{NaCl}$ dozları arasındaki farkın istatistiki olarak önemsiz olduğu bulunmuştur (Çizelge 1).

$\mathrm{NaCl}$ dozlarının (priming) muamele süreleri incelendiğinde ortalama kök kuru ağırlığı $0.19-0.22 \mathrm{~g}$ bitki $^{-1}$ arasında değiştiği görülmüş olup; en yüksek kök kuru ağırlığı $0.22 \mathrm{~g} \mathrm{bitki}^{-1}$ ile kontrol grubunda tespit edilmiştir (Çizelge 8).

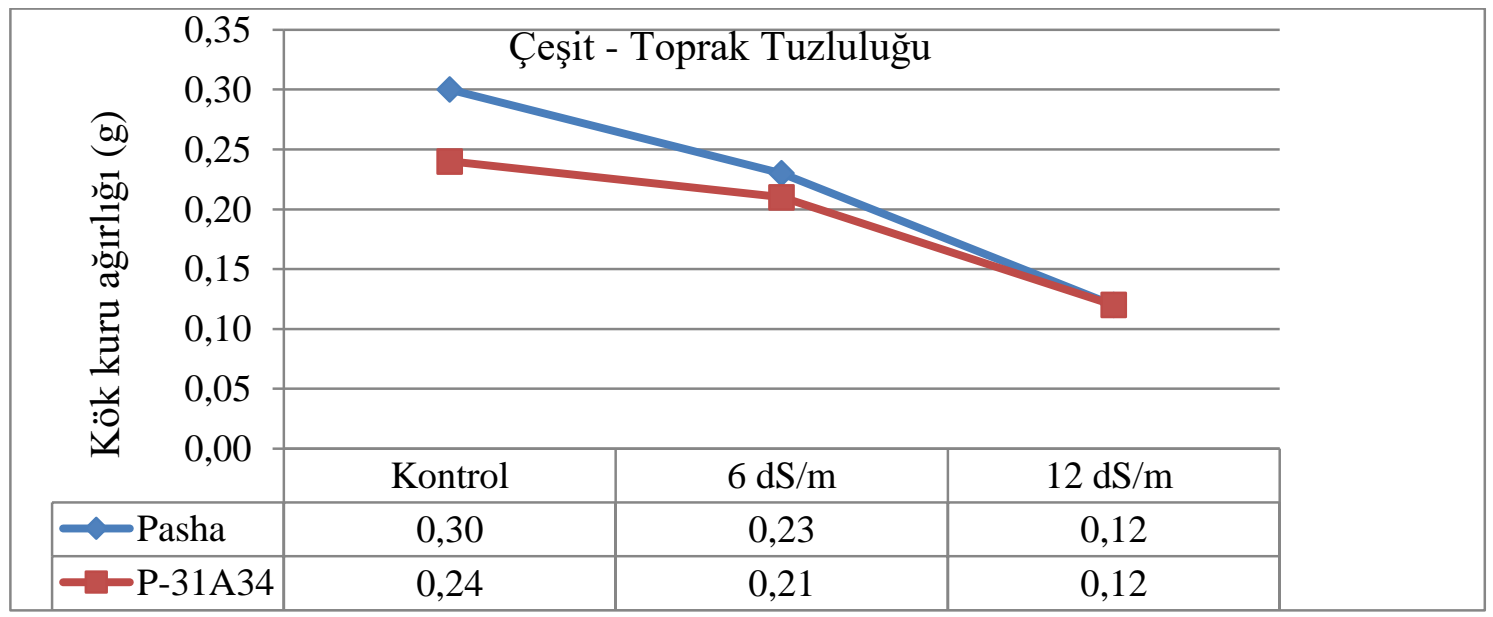

Şekil 4. Çeşit $x$ toprak tuzluluğu etkileşiminde belirlenen kök kuru ağırlıklarına ilişkin ortalama değerler

Figure 4. Average values for root dry weights determined in the interaction of variety $x$ soil salinity

Farklı çeşit $\mathrm{x}$ toprak tuzluluğu etkileşiminde kök kuru ağırlığı yönünden çeşitlerin toprak tuzluluklarına tepkisi istatistiki olarak önemli bulunmuş olup; en yüksek ağırlık (0.30 $\mathrm{g} \mathrm{bitki}^{-1}$ ) Pasha çeşidinde kontrol grubunda 
belirlenirken, en düşük ağırlık ise her iki çeşit için de 12 $\mathrm{dS} \mathrm{m}^{-1}$ toprak tuzluluğunda tespit edilmiştir (Şekil 4). Pasha çeşidinin toprak tuzluluğuna tepkisinin daha yüksek olması interaksiyonun önemli çıkmasına neden olmuştur (Şekil 4).

\section{Sap Azot İçeriği}

Sap azot içeriği değerleri yönünden çeşit, toprak tuzluluğu, muamele süresi, çeşit $x$ muamele süresi, toprak tuzluluğu $x$ muamele süresi, çeşit $x$ toprak tuzluluğu x muamele süresi etkileşiminin önemli olduğu belirlenmiştir.

Sap azot içeriği yönünden P - 31A34 çeşidinin, Pasha çeşidine göre daha yüksek değere sahip olduğu belirlenmiştir (Çizelge 2).

Farklı toprak tuzluluklarında belirlenen sap azot içeriği değerleri 29.44 - $33.13 \mathrm{mg} \mathrm{g}^{-1}$ arasında değişmiş olup en yüksek azot içeriği değeri $33.13 \mathrm{mg} \mathrm{g}^{-1}$ ile EC 12 toprak tuzluluğunda, en düşük değer ise $29.44 \mathrm{mg} \mathrm{g}^{-1}$ ile EC 6 toprak tuzluluğunda belirlenmiştir (Çizelge 2).

Tohumlara uygulanan farklı $\mathrm{NaCl}$ dozlarında (priming) belirlenen sap örneklerine ait ortalama azot değerleri 30.81 - $31.26 \mathrm{mg} \mathrm{g}^{-1}$ arasında değiştiği görülmüş olup; aradaki fark istatistiki olarak önemsiz bulunmuştur (Çizelge 10).

$\mathrm{NaCl}$ dozlarının muamele süreleri incelendiğinde bitki sap örneklerinde azot içeriği değerleri 31.94 - 30.07 mg $\mathrm{g}^{-1}$ arasında değiştiği görülmüş olup; en yüksek değer $31.94 \mathrm{mg} \mathrm{g}^{-1}$ ile 24 saatlik muamele süresinde çıkarken en düşük değer ise kontrol grubunda tespit edilmiştir (Çizelge 2).

Uygulamalara göre bitki sap azot içeriği değerlerinin farklı olması muhtemelen sap kuru ağırlıklarının farklı olmasından kaynaklanmaktadır, çünkü sap kuru ağırlığının daha yüksek belirlendiği uygulamalarda genel olarak daha düşük azot içeriği değerleri elde edilmiştir.

Çizelge 2. Farklı çeşit, toprak tuzluluğu, $\mathrm{NaCl}$ dozu ve muamele süresi uygulamalarında belirlenen sap ve kök azot içeriği, kök/sap oranı ve tuz tolerans indeksine ilişkin ortalama değerler ve EGF çoklu karşılaştırma testine göre oluşan gruplar

Table 2. Average values of stem and root nitrogen content, root / stem ratio and salt tolerance index determined in different cultivars, soil salinity, $\mathrm{NaCl}$ dosage and treatment time applications and groups occurred according to EGF multiple comparison test

\begin{tabular}{|c|c|c|c|c|}
\hline & $\begin{array}{l}\text { Sap Azot İçeriği } \\
\left(\mathrm{mg} \mathrm{g}^{-1}\right)\end{array}$ & $\begin{array}{l}\text { Kök Azot İçeriği } \\
\left(\mathrm{mg} \mathrm{g}^{-1}\right)\end{array}$ & $\begin{array}{l}\text { Kök/Sap oranı } \\
\text { (\%) }\end{array}$ & $\begin{array}{l}\text { Tuz tolereans } \\
\text { İndeksi (\%) }\end{array}$ \\
\hline \multicolumn{5}{|l|}{ Çeşitler } \\
\hline PASHA & $30.02 b$ & 15.33 & $51.47 \mathrm{~b}$ & $100.67 \mathrm{a}$ \\
\hline P-31A34 & $32.15 \mathrm{a}$ & 15.28 & $53.75 \mathrm{a}$ & $93.91 b$ \\
\hline \multicolumn{5}{|c|}{ Toprak Tuzluluğu } \\
\hline Kontrol & $30.68 \mathrm{~b}$ & $14.46 \mathrm{~b}$ & $61.54 \mathrm{a}$ & 97.79 \\
\hline $6 \mathrm{dS} \mathrm{m}^{-1}$ & $29.44 \mathrm{c}$ & $13.97 \mathrm{c}$ & $58.49 \mathrm{~b}$ & 95.54 \\
\hline $12 \mathrm{dS} \mathrm{m}^{-1}$ & $33.13 \mathrm{a}$ & $17.49 \mathrm{a}$ & $37.80 \mathrm{c}$ & 98.53 \\
\hline \multicolumn{5}{|l|}{$\mathrm{NaCl}$ Dozu } \\
\hline $0 \mathrm{~g}^{-1}$ & 31.17 & 15.16 & 52.01 & 95.35 \\
\hline $5 \mathrm{~g} \mathrm{l}^{-1}$ & 31.26 & 15.29 & 52.57 & 97.85 \\
\hline $10 \mathrm{~g} \mathrm{l}^{-1}$ & 30.81 & 15.47 & 53.26 & 98.67 \\
\hline \multicolumn{5}{|c|}{ Muamele Süresi } \\
\hline Kontrol & $30.07 \mathrm{c}$ & $14.87 \mathrm{~b}$ & $56.01 \mathrm{a}$ & 100.00 \\
\hline 12 Saat & $31.24 \mathrm{~b}$ & 15.27 b & $50.38 \mathrm{~b}$ & 95.47 \\
\hline 24 Saat & $31.94 \mathrm{a}$ & 15.77 a & $51.44 \mathrm{~b}$ & 96.39 \\
\hline EGF (\%5) & 0.5345 & 0.3970 & 1.844 & - \\
\hline
\end{tabular}

Aynı harf grubuna giren ortalamalar arasındaki fark EGF testine göre \% 5 düzeyinde önemli değildir.

Mısır bitkisi sap örneklerine ait azot değerleri için, çeşit $\mathrm{x}$ muamele süresi etkileşiminin önemli olduğu saptanmıştır. Sap örnekleri azot içeriği değerleri 29.60 $33.62 \mathrm{mg} \mathrm{g}^{-1}$ arasında değişmiş olup, en yüksek değer
(33.62 $\mathrm{mg} \mathrm{g}^{-1}$ ), P - 31A34 çeşidinde 24 saat muamele süresinde görülürken, en düşük değer Pasha çeşidinde 6 dS m$~^{-1}$ toprak tuzluluğunda (29.60 $\mathrm{mg} \mathrm{g}^{-1}$ ) görülmüştür (Şekil 5). Sap azot(N) içeriği yönünden muamele süresine 
Pasha çeşidi önemli tepki vermezken P-31A34 çeşidi muamele süresindeki artışa olumlu tepki vermiş, bu da interaksiyonun önemli çıkmasına neden olmuştur(Şekil 5).
Çizelge 13' de görüldüğü gibi çeşit $x$ toprak tuzluluğu $x$ muamele süresi etkileşiminin istatistiksel olarak önemli olduğu saptanmıştır.

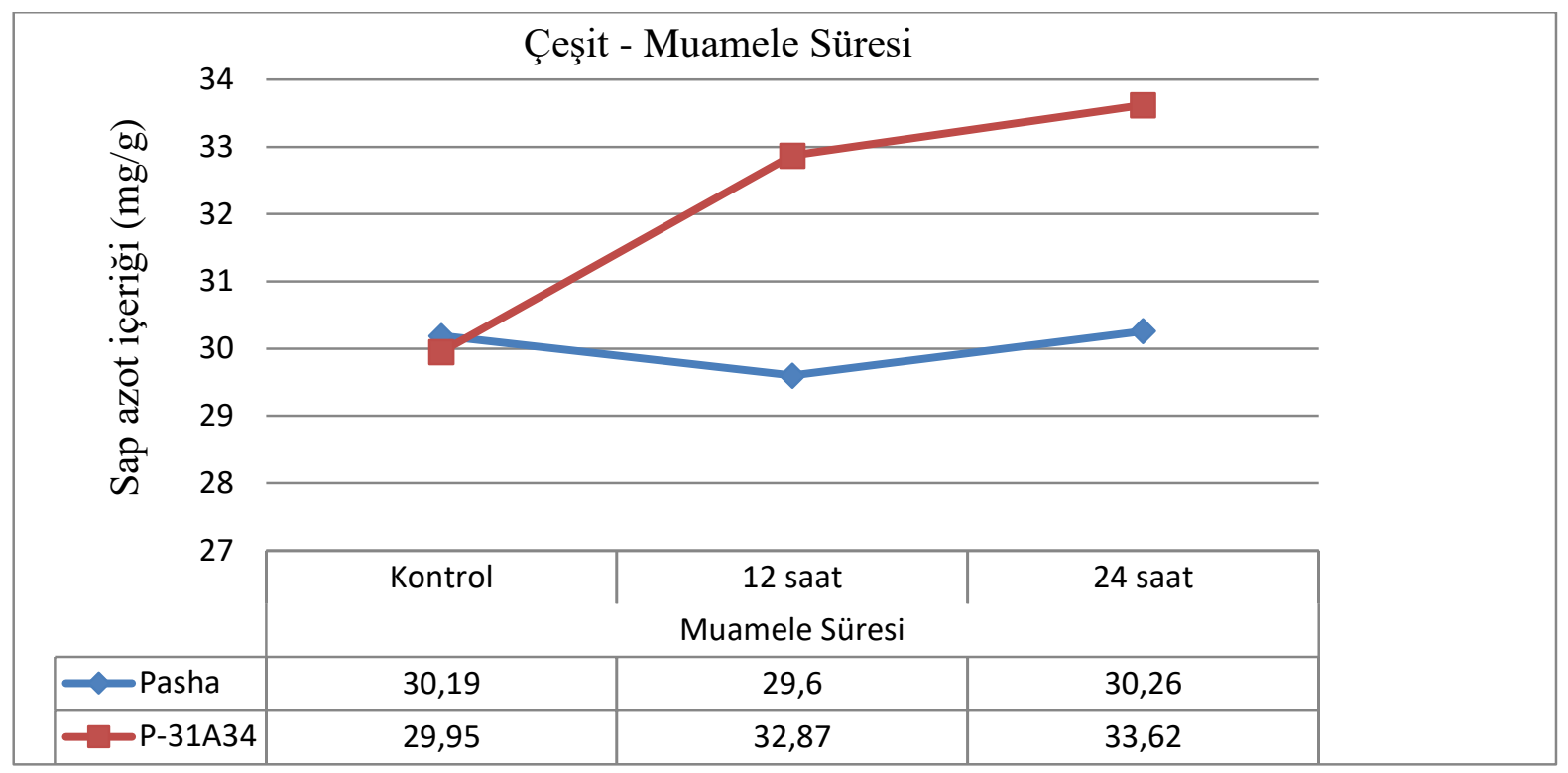

Şekil 5. Çeşit x muamele süresi etkileşiminde belirlenen sap azot içeriğine ait ortalama değerler

Figure 5. Average values of stem nitrogen content determined in the interaction of variety $x$ treatment time

Çizelge 3. Çeşit $x$ toprak tuzluluğu $x$ muamele süresi etkileşiminde belirlen sap azot içeriğine $\left(\mathrm{mg} \mathrm{g}^{-1}\right)$ ait ortalama değerler ve EGF çoklu karşılaştırma testine göre oluşan gruplar

Table 3. Average values of stem nitrogen content $\left(\mathrm{mg} \mathrm{g}^{-1}\right)$ determined in the interaction of variety $x$ soil salinity $x$ treatment time and groups occurred according to EGF multiple comparison test

\begin{tabular}{|c|c|c|c|c|c|}
\hline \multirow{2}{*}{ Toprak Tuzluluğu } & \multirow{2}{*}{ Muamele Süresi } & \multicolumn{4}{|c|}{ Çeşitler } \\
\hline & & Pasha & & $P-31 A 3$ & \\
\hline \multirow{3}{*}{$0 \mathrm{dS} \mathrm{m}^{-1}$} & 0 (kontrol) & 29,73 & $\mathrm{fg}$ & 27,25 & 1 \\
\hline & 12 saat & 28,65 & fgh & 33,57 & bc \\
\hline & 24 saat & 29,65 & $\mathrm{fg}$ & 35,21 & $a$ \\
\hline \multirow{3}{*}{$6 \mathrm{dS} \mathrm{m}^{-1}$} & 0 (kontrol) & 28,03 & hI & 29,86 & $f$ \\
\hline & 12 saat & 28,54 & g-I & 29,95 & $f$ \\
\hline & 24 saat & 28,82 & $f-h$ & 31,46 & e \\
\hline \multirow{3}{*}{$12 \mathrm{dS} \mathrm{m}^{-1}$} & 0 (kontrol) & 32,81 & $\mathrm{~cd}$ & 32,73 & c-e \\
\hline & 12 saat & 31,63 & de & 35,09 & a \\
\hline & 24 saat & 32,32 & $c-e$ & 34,2 & $a b$ \\
\hline
\end{tabular}

Aynı harf grubuna giren ortalamalar arasındaki fark EGF testine göre \% 5 düzeyinde önemli değildir.

Farklı çeşit $\mathrm{x}$ toprak tuzluluğu $\mathrm{x}$ muamele süresi etkileşiminde sap azot içeriği değerleri Pasha çeşidi için; $28.03-32.81 \mathrm{mg} \mathrm{g}^{-1}$ arasında değişmiş olup; en yüksek sap azot içeriği değeri $12 \mathrm{dS} \mathrm{m}^{-1}$ toprak tuzluluğunda ve kontrol grubunda $\left(32.81 \mathrm{mg} \mathrm{g}^{-1}\right)$ görülürken, en düşük değer $6 \mathrm{dS} \mathrm{m}^{-1}$ toprak tuzluluğunda $\left(28.03 \mathrm{mg} \mathrm{g}^{-1}\right)$ ve yine kontrol grubunda görülmüştür. P - $31 \mathrm{~A} 34$ çeşidinin sap azot içeriği ise; $27.25-35.21 \mathrm{mg} \mathrm{g}^{-1}$ arasında değişmiş olup; en yüksek sap azot içeriği değeri kontrol grubunda 24 saat uygulamasında ( $35.21 \mathrm{mg} \mathrm{g}^{-1}$ ) görülürken, en düşük değer de kontrol grubu toprak tuzluluğunda (27.25 mg g${ }^{-1}$ ) belirlenmiştir (Şekil 6). 


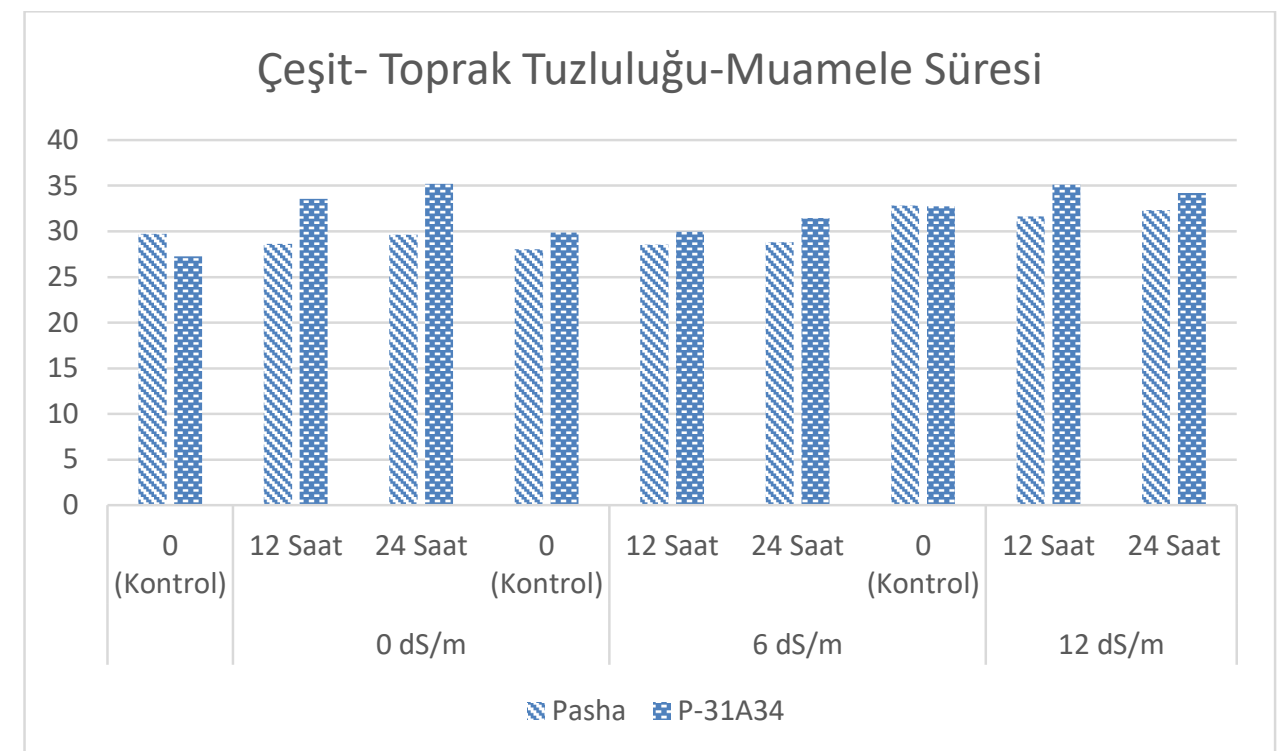

Şekil 6. Çeşit x toprak tuzluluğu x muamele süresi etkileşiminde belirlenen sap azot içeriğine ilişkin ortalama değerler Figure 6. Average values for $s$ nitrogen content determined in the interaction of variety $x$ soil salinity $x$ treatment time

\section{Kök Azot (N) içeriği}

Kök örneklerine ait azot değerleri yönünden toprak tuzluluğu, muamele süresi, çeşit $x$ toprak tuzluluğu etkileşiminin önemli olduğu belirlenmiştir.

Çeşitler arasında kök azot içeriği değeri yönünden istatistiksel olarak fark olmadığı görülmüştür (Çizelge 2). Farklı toprak tuzluluklarında belirlenen kök azot içeriği değerleri 13.97 - $17.49 \mathrm{mg} \mathrm{g}^{-1}$ arasında değişmiş olup en yüksek kök azot içeriği değeri $17.49 \mathrm{mg} \mathrm{g}^{-1}$ ile $12 \mathrm{dS} \mathrm{m}^{-1}$ toprak tuzluluğunda, en düşük değer ise $13.97 \mathrm{mg} \mathrm{g}^{-1}$ ile $6 \mathrm{dS} \mathrm{m}^{-1}$ toprak tuzluluğunda belirlenmiştir (Çizelge 2).
Tohumlara uygulanan farklı $\mathrm{NaCl}$ dozlarında (priming) belirlenen kök örneklerine ait ortalama azot değerleri istatistiki olarak önemsiz bulunurken, bu değerler 15.16 - $15.47 \mathrm{mg} \mathrm{g}^{-1}$ arasında değişmiştir (Çizelge 2).

$\mathrm{NaCl}$ dozlarının (priming) muamele süreleri incelendiğinde kök azot içeriği değerlerinin 14.87 - 15.77 $\mathrm{mg} \mathrm{g}^{-1}$ arasında değiştiği görülmüş olup; en yüksek kök azot içeriği değeri $15.77 \mathrm{mg} \mathrm{g}^{-1}$ ile 24 saatlik uygulamada belirlenirken, en düşük değer ise kontrol grubunda tespit edilmiştir (Çizelge 2).

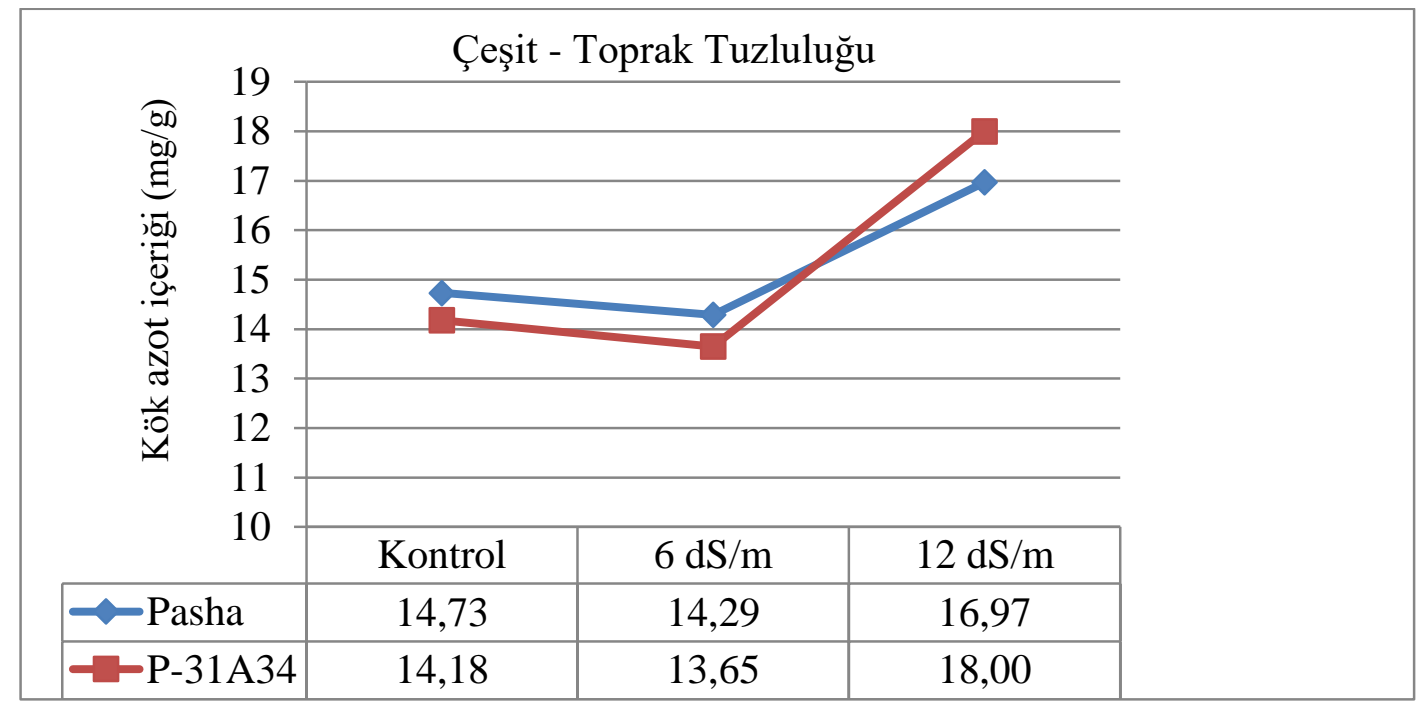

Şekil 7. Çeşit x toprak tuzluluğu etkileşiminde belirlenen kök azot içeriğine ait ortalama değerler Figure 7. Average values of root nitrogen content determined in the interaction of type $x$ soil salinity

Farklı çeşit ve toprak tuzluluğu etkileşiminde kök azot içeriği değerleri 13.65 - $18.00 \mathrm{mg} \mathrm{g}^{-1}$ arasında değişmiş olup; en yüksek kök azot içeriği değeri $\mathrm{P}-31 \mathrm{~A} 34$ çeşidinde $12 \mathrm{dS} \mathrm{m}^{-1}$ toprak tuzluluğunda $\left(18.00 \mathrm{mg} \mathrm{g}^{-1}\right)$ görülürken, en düşük değer P-31A34 çeşidinde $6 \mathrm{dS} \mathrm{m}^{-1}$ toprak tuzluluğunda (13.65 $\left.\mathrm{mg} \mathrm{g}^{-1}\right)$ görülmüştür. 
Çeşitlerin toprak tuzluluğuna tepkisinin farklı olması interaksiyonun önemli çıkmasına neden olmuştur (Şekil 7).

\section{Kök/Sap Oranı}

Kök/sap oranı yönünden çeşitler, toprak tuzluluğu, muamele süresi, çeşitxtoprak tuzluluğu, çeşit $x$ toprak tuzluluğu $x$ muamele süresi etkileşimi önemli bulunmuştur. Kökün sapa oranı pasha çeşidinde 51.47 olarak belirlenirken P-31A34 çeşidinde 53.75 olarak belirlenmiştir (Çizelge 2). Toprak tuzluluğu hem sap hemde kök gelişimini etkilemiş olmakla birlikte kök gelişimi daha fazla etkilendiğinden, toprak tuzluluğundaki artışa bağlı olarak kök/sap oranı değerleri düşü göstermiştir, en yüksek kök/sap oranı 61.54 ile kontrol uygulamasında belirlenirken en düşük değer 37.80 ile $12 \mathrm{dS} \mathrm{m}^{-1}$ toprak tuzluluğunda belirlenmiştir (Çizelge 2).

Tohuma uygulanan $\mathrm{NaCl}$ dozlarının etkisi önemsiz bulunmuş, muamele süresi ise kök gelişimini olumsuz etkilemiştir.

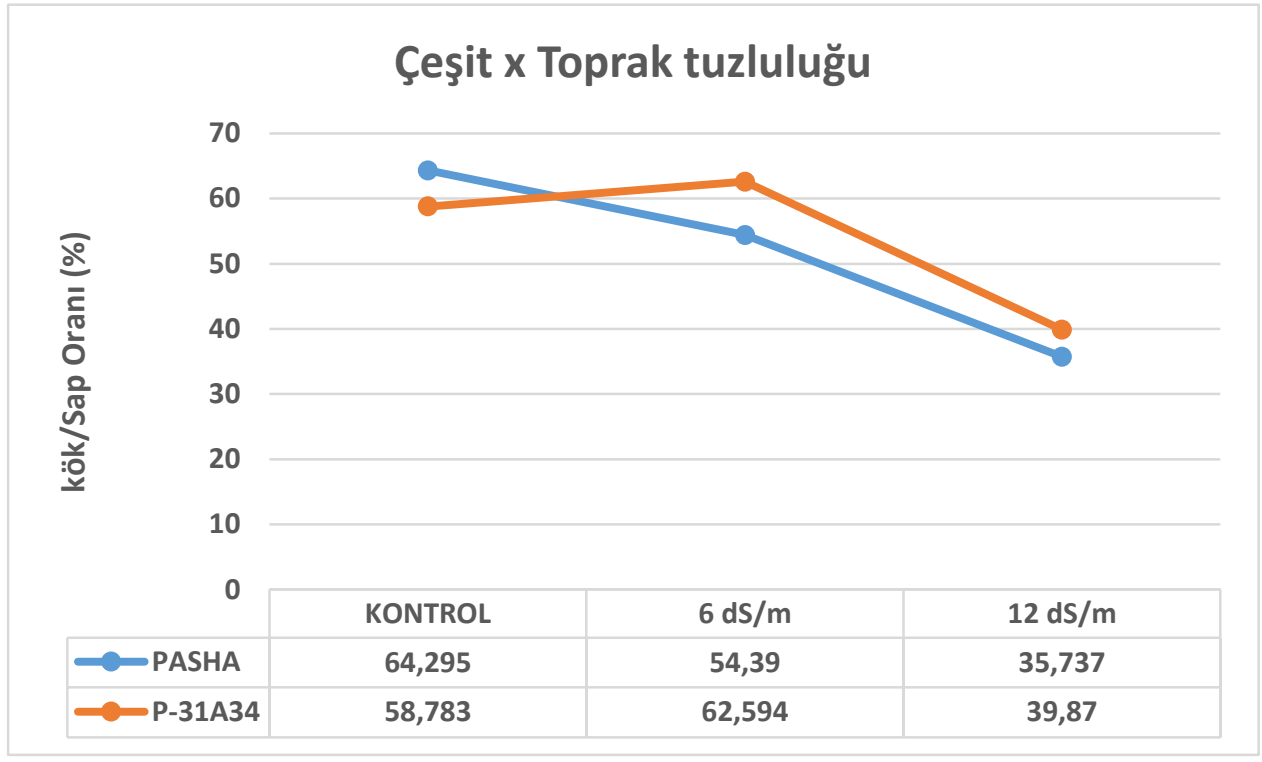

Şekil 8. Çeşit $x$ toprak tuzluluğu etkileşiminde belirlenen kök/sap oranına ait ortalama değerler

Figure 8 . Average values of root / stem ratio determined in the interaction of variety $\mathrm{x}$ soil salinity

Pasha çeşidinde toprak tuzluluğuna bağlı olarak kök/sap oranı azalırken, P-31A34 çeşidinde $6 \mathrm{dS} \mathrm{m}^{-1}$ tuzlulukta bir miktar atış görülmüş ancak $12 \mathrm{dS} \mathrm{m}^{-1}$ tuzlulukta kök/sap oranı yeniden düşmüştür. Çeşitlerin toprak tuzluluğuna farklı tepki göstermesi çeşit $\mathrm{x}$ toprak tuzluluğu etkileşiminin önemli çıkmasına neden olmuştur(Şekil 8).

\section{Tuz tolerans indeksi (\%)}

Tuz tolerans indeksi yönünden sadece çeşitler arasındaki fark önemli bulunmuş olup; diğer uygulamalar arasındaki farklılıklar istatistiksel olarak önemsiz bulunmuştur.

Tuz tolerans indeksi değeri yönünden $P$ - 31A34 çeşidinin, Pasha çeşidine göre daha düşük indeks değerine sahip olduğu belirlenmiştir (Çizelge 2). Çeşitlerin tuz tolerans indeks değerlerinin farklı olması çeşitlerin genetik yapısının farklı olmasından kaynaklanmaktadır.

Farklı toprak tuzluluklarında belirlenen tuz tolerans indeksi değerleri 95.54-98.53 arasında değişmekle birlikte fark istatistiksel olarak önemsiz bunmuştur (Çizelge 2). Tohumlara uygulanan farklı $\mathrm{NaCl}$ dozlarında (priming) tuz tolerans indeksi değerleri arasındaki fark istatistiksel olarak önemsiz bulunmuş olmakla birlikte tohumlara uygulanan $\mathrm{NaCl}$ dozları tuz tolerans indeksi üzerinde olumlu etki yapmıştır (Çizelge 2).

$\mathrm{NaCl}$ dozlarının (priming) muamele süreleri incelendiğinde tuz tolerans indeksi değerleri arasındaki fark istatistiksel olarak önemsiz bulunmuş olmakla birlikte olumsuz etki yapmıştır (Çizelge 2 ).

Sonuç olarak; $\mathrm{NaCl}^{\prime}$ nin farklı dozları $\left(0 \mathrm{~g} \mathrm{l}^{-1}, 5 \mathrm{~g} \mathrm{l}^{-1}\right.$ ve 10 $\left.\mathrm{g}^{-1} \mathrm{NaCl}\right)$ ile farklı sürelerde $(0,12$ ve 24 saat sürelerle ) muamele edilen farklı iki mısır çeşidinin (Pasha ve P31A34) farklı düzeylerde tuz içeren (kontrol, $6 \mathrm{dS} \mathrm{m}^{-1}$ ve

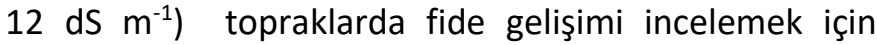
yürütülmüş olan bu çalışma sonucunda uygulamaların fide gelişimi üzerine önemli etkileri olduğu görülmüştür. İncelenen özellikler yönünden çeşitler arasında farklılıkların önemli olduğu, toprak tuzluluğuna bağıı 
olarak fide özelliklerinin olumsuz etkilendiği belirlenmiştir. Toprak tuzluluk düzeyi arttıkça bitki gelişimi daha fazla etkilenmiş, özellikle kök gelişimi sap gelişimine göre daha fazla etkilenmiştir. Çeşitlerin toprak tuzluluğuna tepkisinin farklı olması kök/sap oranında da etkisini göstermiş ve çeşit $x$ toprak tuzluluğu etkileşiminin önemli çıkmasına neden olmuştur. Çalışma sonucunda, tuzluluk problemi olan topraklarda çeşit seçiminin önemli olduğu ve tohumun $5 \mathrm{~g} \mathrm{l}^{-1} \mathrm{NaCl}$ ile muamele edilmesinin fide gelişimi üzerine olumlu etki yaptığı belirlenmiştir.

\section{ÖZET}

Amaç: $\mathrm{Bu}$ çalışma, $\mathrm{NaCl}$ ile muamele edilen mısır tohumlarının tuzlu topraklarda fide gelişimini belirlenmek amacıyla yapılmıştır.

Yöntem ve Bulgular: Çalışmada NaCl'nin farklı dozları (0 $\mathrm{gl}^{-1}, 5 \mathrm{gl}^{-1}$ ve $\left.10 \mathrm{gl}^{-1} \mathrm{NaCl}\right)$ ile farklı sürelerde $(0,12$ ve 24 saat sürelerle) muamele edilen farklı iki mısır çeşidinin (Pasha ve P-31A34) farklı düzeylerde tuz içeren (kontrol, $6 \mathrm{dS} \mathrm{m}^{-1}$ ve $12 \mathrm{dS} \mathrm{m}^{-1}$ ) topraklarda fide gelişimi ile ilgili özellikler incelenmiştir. Çalışma sonucunda çeşitlerin toprak tuzluluğuna tepkisinin farklı olduğu, toprak tuzluluğundaki artışa bağlı olarak bitki boyu sap yaşağırlığı, sap kuru ağırlığı, kök yaş ağırlı, kök kuru ağırlığı, kök/sap oranı ve tuz tolerans indeksi olumsuz etkilenmiş, tohumların ekim öncesinde $5 \mathrm{~g} \mathrm{l}^{-1} \mathrm{NaCl}$ ile muamele edilmesinin incelenen özellikler üzerinde olumlu etki yaptığı belirlenmiştir.

Genel Yorum: Çalışma sonucunda incelenen özellikler yönünden çeşitler arasında farklılıklar olduğu, toprak tuzluluğundaki artışa bağı olarak fide özelliklerinin olumsuz etkilendiği, tohumun $5 \mathrm{~g} \mathrm{l}^{-1} \mathrm{NaCl}$ ile muamele edilmesinin fide gelişimi üzerine olumlu etki yaptığı belirlenmiş olup tuzluluk problemi olan topraklarda çeşit seçiminin önemli olduğu belirlenmiştir.

Çalışmanın Önemi ve Etkisi: Elde edilen sonuçlar toprak tuzluğundaki artıştan bitki gelişiminin olumsuz etkilendiğini, çeşitlerin toprak tuzluluğuna toleranslarının farklılık gösterdiğini, özellikle tuz problemi olan topraklarda çeşit seçimine dikkat edilmesi gerektiğini ortaya koymuştur.

Anahtar Kelimeler: Mısır, Tuz, Tolerans, Ön uygulama, $\mathrm{NaCl}$.

\section{TEŞEKKÜR}

Yüksek Lisans tezi olarak yürütülen bu çalışma, Mustafa Kemal Üniversitesi BAP birimi tarafından (12821 nolu proje) desteklenmiştir.

\section{ÇIKAR ÇATIŞMA BEYANI}

Yazar(lar) çalışma konusunda çıkar çatışmasının olmadığını beyan eder.

\section{ARAŞTIRMACILARIN KATKI ORANI BEYANI}

Yazarlar çalışmaya eşit oranda katkı sağlamış olduklarını beyan eder.

\section{KAYNAKLAR}

Abraha, B. and Yohannes, G., 2013. The role of seed priming in improving seedling growth of maize (zea mays I.) under salt stress at field conditions. African Journal of Biotechnology, 12(46), 6484-6490.

Akdoğan, S. ve Özkan, İ., 2000. Gelişsmenin değişik dönemlerinde uygulanan su noksanlığı geriliminin biber bitkisi (capsicum annuum I.)'nin tuza duyarlılı̆̆ üzerine etkisi. Tarım Bilimleri Dergisi, 6 (3), 1-8.

Akram, M., Ashrafh, M. Y.,Ahmad, R., Waraich, E. A., Iqbal, J. and Mohsan, M., 2010. Screening for salt tolerance in maize (Zea Mays L.) hybrids at an early seedling stage. Pak. J. Bot., 42(1): 141-154.

Aktaş, H., Abak, K., Öztürk, L. ve Çakmak, I.., 2006. The effect of zinc on growthand shoot concentrations of sodium and potassium in pepper plants under salinity stress. Turk J. Agric. For. 30, 407-412.

Anonim, 2019. Türkiye İstatistik Kurumu, http://www.tuik.gov.tr ErişimTarihi: 19.03.2020.

Atasoy, A. ve Geçen, R., 2013. Reyhanlı İlçesi topraklarında tuzlanma problemi. Türk Coğrafya Dergisi, 62: 21-28, ìstanbul.

Atış, İ., 2011. Bazı silajlık sorgum (sorghum bicolor I. moench) çesitlerininçimlenmesi ve fide gelisimi üzerine tuz stresinin etkileri. Süleyman Demirel Üniversitesi Ziraat Fakültesi Dergisi, 6 (2):58-67, 201.

Aymen, E. M, and Cherif, H., 2012. Seed priming to improve germination and seedling growth of safflower (Carthamus tinctorius) under salt stress. EurAsian Journal of BioSciences, 6, 76-84, Tunus.

Aymen, E. M, and Cherif, H., 2013. Influence of seed priming on emergence and growth of coriander (Coriandrum sativum L.) seedlings grown under salt stress. Acta agriculturae Slovenica, 101-1, marec.

Aymen, E. M., Meriem, B. F., Kaouther, Z. and Cherif. H., 2014. Influence of $\mathrm{NACl}$ seed priming on growth and some biochemical attributes of safflower under saline conditions. Research on Crop Ecophysiology. 9(1) 13-20. 
Bajehbaj, A. A., 2010. The effects of $\mathrm{NaCl}$ priming on salt tolerance in sunflower germination and seedling grown under salinity conditions. Africans Journal of Biotechnology, 9 (12), 1764-1770,22.

Bakht, J., Shafi, M., Jamal, Y. and Sher, H., 2011. Responce of maize to seed priming with $\mathrm{NaCl}$ and salinity stress. Spanish Journal of Agricultural Research. 9(1).252-261.

Çelik, A., 2014. Nitrik oksit uygulamasının tuz stresi altında yetiştirilen mısır bitkisinin mineral beslenmesi ve bazı fizyolojik özellikleri üzerine etkisi. Süleyman Demirel Üniversitesi Fen Bilimleri Enstitüsü Yüksek Lisans Tezi.

Eker, S., Cömertpay, G., Konuşkan, Ö., Ülger, A. C., Öztürk, L. Ve Çakmak, i. (2006) Effect of salinity stress on dry matter production and ion accumulation in hybrid maize varieties. Turk. J. Agric. For. 30,365-373

Ekmekçi, E., Apan, M. ve Kara, T., 2005. Tuzluluğun bitki gelişimine etkisi, OMÜ Zir. Fak. Dergisi, 20 (3): 118125.

Idikut, L., Dumlupınar Z., Kara S.N., Yururdurmaz, and C., Colkesen, M., 2012, The effect of different temperatures and salt concentrations on some popcorn landraces and hybrid corn genotype germinations. Pak. J. of Botany, $\quad$ 44(2):579-589.

Khan, H. A., Ayub, C.M., Pervez, M. A., Bilal, R. M., Shahid, M. A. and Ziaf, K., 2009. Effect of seed priming with $\mathrm{NaCl}$ on salinity tolerance of hot pepper (Capsicum annum L.) at seedling stage. Soil\&Environ. 28(1): 81-87, Pakistan.

Koçer, M. C., 2007. Tuz stresine maruz bırakılan mısır (Zea Mays L.) bitkisinde, eksojen olarak uygulanan absizik asit (aba) ve salisilik asit (sa)'nın etkilerinin belirlenmesi. Yüzüncü Yıl Üni. Fen Bilimleri Enstitüsü Biyoloji Anabilim Dalı, Yüksek Lisans Tezi.
Köşkeroğlu, S., 2006. Tuz ve stresi altındaki mısır (Zea Mays L.) bitkisinde prolin birikim düzeyleri ve stres parametrelerinin araştırılması, Muğla Üni. Fen Bilimleri Enstitüsü Yüksek Lisans Tezi.

Marschner, H., 1995. Mineral nutrition of higher plants, Academic Press, 657-680.222.

Miraj,G., Shah, H. U. and Arif, M., 2013. Priming mays (Zea mays) seed with phosphate solutions improves seedling growth and yield. The Journal of Animal \&Plant Sciences, 23 (3): 893-899, ISSN: 10187081, Pakistan.

Sathish, S., Sundareswaran, S, and Ganesan, N., 2011. Influence of seed priming on physiological performance of fresh and aged seeds of maize hybrid $\mathrm{COH}(\mathrm{M}) 5$ and it's parental lines. Asian Research Publishing Network (APRN), 6 (3), ISSN 1990-6145, India.

Shaw, R. H., 1988. Climate Requirement Corn and Corn Improvement. ASA, CSSA, SSSA, 609-638, Wisconsin, USA.

Sönmez, B., 2004.Türkiye' de çorak ıslahı araştırmaları ve tuzlu toprakların yönetimi. Sulanan Alanlarda Tuzluluk Yönetimi Sempozyumu Bildiriler Kitabı, 2021 Mayıs, Ankara, 157-162.

Tian, Y., B. Guan, D. Zhou, J. Yu, G. Li, Y. Lou., 2014. Responses of seed germination, seedling growth and seed field traits to seed pretraitment in maize. The Scintific World Journal. Article ID 834630, 8 pages.

Yalçın, M., 2004. Amik Ovası topraklarının temel kimyasal ve fiziksel özelliklerinin belirlenmesi, MKÜ, Fen Bilimleri Ens. Yüksek Lisans Tezi. 